https://doi.org/10.48009/2_iis_2010_30-36

\title{
THE HYPE OF USING SOCIAL NETWORKING AS A TOOL FOR LEARNING IN E- LEARNING
}

\author{
Alex Koohang, Macon State College, USA, alex.koohang@maconstate.edu \\ Kevin Floyd, Macon State College, USA, kevin.floyd@ maconstate.edu \\ Terry Smith, Macon State College, USA, terry.smith1 @ maconstate.edu \\ Robert Skovira, Robert Morris University, USA, skovira@rmu.edu
}

\begin{abstract}
This paper examines the hype about using social networking as a tool to promote learning in $e$ learning environments. Specifically, the validity of the following assertions are delineated and discussed: 1) constructing knowledge using social networking, 2) creating learning communities using social networking, and 3) building communities of practice using social networking.
\end{abstract}

Keywords: Social networking, Constructivism, learning community, community of practice, elearning

\section{INTRODUCTION}

Social networking sites such as Facebook, Twitter, LinkedIn, etc. are gaining momentum among people who would like to stay connected with one another. These sites allow individuals to build communities. In these communities, individuals meet each other, make friends, share information, interests, and activities.

Social networking is included as a part of social media. Social media is user-generated Web content that is shared by social interaction. Kaplan and Haenlein (2010) define social media as "a group of Internet-based applications that build on the ideological and technological foundations of Web 2.0, and that allow the creation and exchange of usergenerated content." Examples of social media are: Blogging (i.e., Wordpress, Edublogs, Blogpot); Building three-dimensional content in virtual worlds (i.e., Second Life); Micro-blogging (i.e., Twitter); Private social networking (i.e., Ning); Public social networking sites (i.e., Facebook, MySpace, Linkedin); Sharing of images (i.e., Flickr); Sharing of presentations (i.e., Slideshare); Sharing of videos (i.e., YouTube); Social bookmarking and tagging (i.e., Delicious, Diigo); Social news sites (i.e., Digg); Voice, chat, \& video conferencing (i.e., Skype); and Wikis (i.e., Wikipedia, GoogleWave).

E-learning is defined as "... the delivery of education (all activities relevant to instructing, teaching, and learning) through various electronic media." (Koohang \& Harman, 2005) E-learning or distance education is progressively being adopted among students in higher education institutions. A report in 2006 by Allen and Seaman indicated that 3.2 million students in the USA, mostly undergraduates, were taking at least one online course in fall 2005 term. Allen and Seaman (2008) indicated that online enrollments have been growing significantly faster than the higher education enrollments in general.

The most recent report published by Sloan Consortium, Allen and Seaman (2009) reported that enrollment for e-learning continues to grow rapidly. The following highlights were noted in their report:

- "Over 4.6 million students were taking at least one online course during the fall 2008 term; a 17 percent increase over the number reported the previous year.

- The 17 percent growth rate for online enrollments far exceeds the 1.2 percent growth of the overall higher education student population.

- More than one in four college and university students now take at least one course online." (Allen \& Seaman, 2009)

\section{SOCIAL NETWORKING AND E-LEARNING}

Web 2.0 technologies are growing in popularity. According to Alexander (2006), society has undergone significant change through a tsunami-like flood of innovation tools and services that foster new methods of collaboration and social networking. The rapid growth of Web-based tools such as blogs, 
wikis, social networking, and bookmarking offer rich user experiences where the process of knowing is a community-based collaborative endeavor.

In 2004, Tim O'Rielly of O'Rielly Media used the phrase Web 2.0 to refer to the second generation of Web-based services that emphasize online collaboration, interoperability, user-centered design, and sharing of information among users (O'Rielly, 2005).

According to Huang and Behara (2007), the exact meaning of Web 2.0 remains open to debate, but is most often associated with Web platforms that support growing content and functionality that allows users to contribute, manage, share, and own their own data. In addition, Web 2.0 technologies promote social networking in a virtual environment by permitting the generation and distribution of Web content in an open, decentralized, and conversational fashion by and for end users.

Another characteristic of Web 2.0 is its use of improved web technologies such as weblogs, social bookmarking, wikis, podcasts, online videos, RSS feeds, social software, and other web services. Web 2.0 sites differ from standard or Web 1.0 sites where users are limited to the passive viewing of information that is provided to them (Huang \& Behara, 2007).

Huang and Behara (2007) also noted that Web 2.0 tools are becoming popular as learning tools because they allow students to utilize tools that are becoming indispensible parts of students' daily lives.

In addition, Web 2.0 technologies are being used to present new opportunities for developing and supporting diverse online learning environments and enhancing interactivity, participation, and feedback between students, student peer groups, and teachers (Harrison \& Thomas, 2009).

\section{PURPOSE OF THE PAPER}

The growing hype about using social networking as a tool to promote learning in e-learning environments extends to assertions that in e-learning environments 1) "constructivism" learning theory can measure up to social networking (DiScipio, 2008; Reynard, 2009); 2) "learning communities" can be created with social networking (Reynard, 2009); and 3) "communities of practice" can be built with social networking (Gunawardena, Hermans, Sanchez, Richmond, Bohley, \& Tuttle, 2009). The purpose of this paper is to delineate and discuss the validity of these assertions.

\section{SOCIAL NETWORKING AND CONSTRUCTIVISM}

While skeptical, Reynard (2009) stated that instructors can engage students to construct knowledge within social networking environment if they do the following:

- "Maintain a constant presence

- Use a variety of supporting tools to process information such as blogs, wikis, microblogs, etc.

- Actively synthesize broadly scoped ideas into workable focus areas

- Continue to engage students" (Reynard, 2009)

We argue that constructing knowledge goes beyond merely the above tasks. In a less controlled, passive, and "anything goes" social networking environment; it is difficult to construct new knowledge.

Koohang, Riley, Smith, and Schreurs (2009) presented a learner-centered model for e-learning design based on constructivism learning theory. The model encourages learners to actively construct new knowledge. This model includes two categories - the learning design elements and the learning assessment elements. The learning design elements consist of fundamental design elements and collaborative design element. The fundamental design elements are essential for designing learning activities. The collaborative design elements are essential for collaboration and constructing new knowledge.

The model encourages learners to actively construct new knowledge. This is accomplished in three stages.

Stage one requires the following:

- The learner is presented with a real-world situation

- The learner is encouraged to develop his/her own goals and objectives in solving problems

- The learner is encouraged to do exploration

- The learner controls his/her learning 
- The learner is asked to include and apply his/her own previous experience and knowledge in a situation

- Interrelatedness and interdisciplinary learning are encouraged

- The learner is asked to reflect on what he/she has learned

- The learner should be required to give justification for his or her answers, and scaffolding becomes a vital learning means

- The learner is required to go beyond what he/she has learned

Stage two requires that learners be placed in teams to collaboratively construct knowledge based on what they have collected in stage one. The following are required in stage two:

- Learners cooperate

- Learners collaborate

- Learners present multiple perspectives

- Learners present a variety of content, ideas, and/or concepts

- Social negotiation/interaction among learners are carried out

Stage three deals with the self assessment, team assessment, and facilitator/professor assessment. The facilitator/professor constantly coaches, mentors, and/or guides learners. The facilitator/professor values learners and provides them with continuous feedback (Koohang, et al., 2009).

As can be seen from this model, constructing new knowledge is a systemic approach that requires a controlled environment with careful activity/assignment design that includes the fundamental design of constructivism and the design of collaboration with on-going self, team, and instructor assessments.

\section{SOCIAL NETWORKING AND LEARNING COMMUNITY}

A Social Networking site is a community of people created by its members with shared interests, hobbies, etc. A Social Networking site is a community, but it is not a community of learning. A reasonable distinction between a community that engages in entertainment, news, etc. and a learning community is described below by Wilson and Ryder (n.d.):
"In truth, all communities learn. One of the lessons of postmodernism and situated cognition is that learning cannot be separated from action. We are learning every day, in everything we do. We add the qualifying term to our definition to suggest a community sharing a consensual goal to support each other in learning. Everybody expects to learn and is prepared to engage in activities at least partly for that reason. This would distinguish learning communities from those solely concerned with entertainment, political action, or the performance of an immediate task." (Wilson \& Ryder, n.d.)

Wilson and Ryder (n.d.) state that members of a learning community share control of learning. All members in this community learn by continuous engagements. These members are groups of people that form a learning community, also known as a dynamic learning community. They are described by the following characteristics:

- "distributed control;

- commitment to the generation and sharing of new knowledge;

- flexible and negotiated learning activities;

- autonomous community members;

- high levels of dialogue, interaction, and collaboration;

- a shared goal, problem, or project that brings a common focus and incentive to work together." (Wilson \& Ryder, n.d.)

We argue that while a community can be built through social networking, this community is not necessarily a learning community. Listed below, we compare the characteristics of a dynamic learning community with a social networking site.

\section{Characteristics of a Learning Community}

- Endorses distributed control.

- Members are committed to the generating and sharing of new knowledge.

- The environment includes flexible and negotiated learning activities.

- Members are autonomous \& selfdetermined in a distributed environment. They set goals and objectives.

- There are high levels of dialogue, interaction, and collaboration among members. 
- Members have a shared goal, problem, or project that brings a common focus and incentive to work together. (Wilson \& Ryder, n.d.)

\section{Characteristics of a Social Networking Site}

- There is absence of control. The environment is informal

- Members generate and share information - there is no required commitment

- Members share interests/activities, but there are no negotiated learning activities

- There is no need for members to be autonomous and self-directed. Members do not set goals and objectives.

- Members engage in passive and informal dialogue/ interaction/cooperation.

- Members do not have a shared goal This is an environment with no rules or limits. Members have no incentives to work collaboratively.

As can be seen above, a social networking site can be referred to a community; however, this community is not a learning community because unlike a community of learning, members of a social networking site do not have commitment to share and create knowledge. There is no distributed control and interactions are informal and passive. They do not have a common goal or commitment that brings them together. In a social networking community, there is no incentive for members to work together.

\section{SOCIAL NETWORKING AND COMMUNITY OF PRACTICE}

A community of practice possesses a mission. Its main goal is to solve problems. A community of practice is an active setting in which learning takes place by doing. (Lave, 1991)

Wenger (2006) stated that "Communities of practice are formed by people who engage in a process of collective learning in a shared domain of human endeavor.“
A community of practice is not just a "club of friends" or "connection between people". It is not just a community with similar interests and hobbies. A community of practice has a mission and identity. The identity is defined by a shared domain of interest that entails commitment among the members to use their skills and abilities to learn from each other. A community of practice actively engages in joint activities. They help, share, and build "relationships that enable them to learn from each other." In a community of practice, members are "practitioners" who develop shared practice and continuously maintain interaction in order to learn. (Wenger, 2006)

A community of practice is comprised of three essential characteristics. They are the domain, the community, and the practice (Wenger, 2006). Below, we compare Wenger's three essential characteristics of a community of practice with a social networking site.

\section{Three Characteristics of A Community of Practice - CoP (Wenger, 2006)}

\section{The domain}

- A CoP is not merely a club of friends or a network of connections between people.

- A CoP has an identity defined by a shared domain of interest.

- Membership in a CoP implies a commitment to the domain.

- Members of a CoP have a shared set of abilities and skills.

- Members of a CoP value their collective competence.

- Members of a CoP learn from each other.

The community

- Members of a CoP engage in joint activities and discussions.

- Members of a CoP help each other.

- Members of a CoP share information.

- Members of a CoP build relationships that enable them to learn from each other.

\section{The practice}

- A CoP is not merely a community of interest - people who like certain kinds of movies, hobbies, etc.

- Members of a CoP are practitioners.

- Members of a CoP develop a shared practice. 
- Members of a CoP take time and sustain interaction.

\section{A Social Networking Site (SNS)}

\section{The domain}

- A SNS is a merely a club of friends or a network of connections between people.

- A SNS may or may not lack a defined identity by a shared domain of interest.

- There is no member commitment in a SNS.

- Members of a SNS may or may have a set of shared abilities and skills.

- Members of a SNS may or may not value their collective competence.

- Members of a SNS may or may not learn from each other.

\section{The community}

- Members of a SNS engage in activities and discussions.

- Members of a SNS may help each other.

- Members of a SNS share information.

- Members of a SNS build relationships that may or may not enable them to learn from each other.

\section{The practice}

- A SNS is a community of interest - people who like certain kinds of movies, hobbies, etc.

- Members of a SNS may or may not be practitioners. Being a practitioner is not required of members of a SNS.

- Members of a SNS do not develop a shared practice.

- Members of a SNS do not necessarily take time and do not necessarily sustain interaction.

From the comparison above, one can ascertain that in a social networking site the community is the only characteristic that is typically common with a community of practice. A social networking site lacks the characteristics inherent to the domain and the practice; therefore, it is not and cannot be called a community of practice. A community of practice includes all three characteristics - the domain, the community, and the practice.

\section{DISCUSSION}

Based on the Demand Driven Learning Module (MacDonald, Stodel, Farres, Breithaupt, \& Gabriel, 2001) there are "...five inter-related dimensions that in concert create a high-quality eLearning experience: structure (the foundation for quality content, delivery, and service), content (comprehensive, authentic, and researched), delivery (usability, interactivity, and tools), service (resources, administration and technical support, accessibility, and responsiveness), and outcomes (lower costs for the learner and employer, personal advantages, and achievement of learning outcomes)" (c.f. Thompson \& MacDonald, 2005, p. 234-235).

As can be seen above, the delivery dimension here is the technology. Technology is only one element of the five inter-related dimensions that contribute to quality e-learning experience.

E-learning relies upon information technology to extend the learning process beyond the walls of any campus resulting in a virtual classroom (Koohang \& Harman, 2005). Learning is an active process. In the process the learner constructs knowledge based on his/her prior knowledge and experience. This paper has argued that a social networking site is not suitable for learners to construct knowledge, create learning communities, or build communities of practice in e-learning environments.

A content management system such as Blackboard/WebCT, Desire2Learn (proprietary), Moodle, Sakai (open source) is normally used to extend the learning at a distance. A content management system (also known as courseware) is the information technology that is used to create the virtual classroom or the environment in which online learning takes place.

Today, content management systems offer many tools that course designers, instructors, and students can use throughout the learning process. These tools include asynchronous communication through discussion forums (to create highly effective social interaction that leads to constructing knowledge); social media tools such as wikis (to aid the building/sharing/constructing knowledge) and blogs (to discuss trends, etc.). Links to external resources for students such as podcasting, video and image sharing can be provided within a content management system to aid the learning process. In addition, a content management system includes tools such as grade books; assignment submission 
facilities; links to lectures; email; and syllabi to aid the management of the virtual classroom.

A content management system is typically the delivery dimension of e-learning and goes way beyond a typical social networking site. A content management system is equipped to offer learners the ability to construct knowledge, create learning communities, or build communities of practice in elearning environments. Unlike a social networking site, all of these can be accomplished in a distributed controlled environment with commitment from the members to actively collaborate and construct knowledge. This environment has a real mission and a real identity. Members are self-directed with a common goal. The goal is to collaboratively construct knowledge by actively engaging, negotiating, participating, interacting, and assessing. In addition, this environment provides coaching, mentoring, guidance, and evaluation.

Technology as a tool can enable and facilitate learning. Technology does not drive learning. The use of technology in the process of learning is based on the goals and objectives that support learning. Social media technology can lend themselves as tools to improve learning, but not all social media are suitable enough to be used as tools to aid learning. As this paper described, a social networking site is not suitable for constructing knowledge, creating communities of learning, and building communities of practice in e-learning environments.

Social media tools such as wikis, blogs, podcasting, video sharing, image sharing, voice conferencing, and video conferencing are powerful tools that can lend themselves to learning. Each of these tools must serve a particular need in the learning process. They should not be used if they don't have a purpose in the learning process. The use of these tools to facilitate learning must be in a distributed, controlled, and managed learning environment such as a content management system.

\section{REFERENCES}

1. Alexander, B. (2006). Web 2.0: A new wave of innovation for teaching and learning? Educause Review, 41(2), 32-44.

2. Allen, E. \& Seaman, J. (2009). Learning on Demand: Online Education in the United
States, 2009. The Sloan Consortium. Retrieved February 26, 2010 from http://www.sloan-

c.org/publications/survey/pdf/learningonde mand.pdf

3. Allen, E., \& Seaman, J. (2006). Making the grade: Online education in the United States. The Sloan Consortium. Retrieved October 19, 2008 from http://www.sloanc.org/publications/survey/p df/making the grade.pdf

4. Allen, E., \& Seaman, J. (2008). Online nation: Five years of growth in online learning. The Sloan Consortium. Retrieved October 19, 2008 from http://sloanc.org/publications/survey/online nation

5. DiScipio, T. (2008). Adapting social networking to address 21 st-century skills. MultiMedia \&Internet@Schools, 15(5),1011.

6. Gunawardena, C., Hermans, M., Sanchez, D., Richmond, C., Bohley, M., \& Tuttle, R. (2009). A theoretical framework for building online communities of practice with social networking tools. Educational Media International, 46(1), 3-16.

7. Harrison, R., \& Thomas, M. (2009). Identity in online communities: Social networking sites and language learning. International Journal of Emerging Technologies and Society, 7(2), 109-124.

8. Huang, D. C., \& Behara, R. S. (2007). Outcome-driven experimental learning with web 2.0. Journal of Information Systems Education, 18(3), 329 - 336.

9. Kaplan A. and Haenlein M. (2010), Users of the world, unite! The challenges and opportunities of social media, Business Horizons, 53(1), p. 59-68.

10. Koohang, A., Riley, L., Smith, T. \& Schreurs, J. (2009). E-Learning and Constructivism: From Theory to Application. Interdisciplinary Journal of ELearning \& Learning Objects, 5(1), 91-109. 
11. Koohang, A., \& Harman, K. (2005). Open source: A metaphor for e-learning. Informing Science: The International Journal of an Emerging Transdiscipline, 8, 75-86. Retrieved from http://inform.nu/Articles/Vol8/v8p075086Kooh.pdf

12. Lave, J. (1991) 'Situated learning in communities of practice', in Resnick, L., Levine, J. and Teasley, S. (Eds.): Perspectives on Socially Shared Cognition, American Psychological Association, Washington DC, pp.63-82.

13. MacDonald, C.J., Stodel, E., Farres, L., Breithaupt, K., \& Gabriel, M.A. (2001). The demand driven learning model: A framework for web-based learning. The Internet and Higher Education,4(1), 9-30.

14. O'Reilly, T. (2005). What is web 2.0. Retrieved March 6, 2010 from http://www.oreillynet.com/pub/a/oreilly/tim/ news/2005/09/30/what-is-web-20.html

15. Reynard, R. (2009). Beyond Social Networking: Building Toward Learning Communities. T.H.E. Journal. Retrieved March 07, 2010 from http://thejournal.com/Articles/2009/07/15/B eyond-Social-Networking-Building-TowardLearning-Communities.aspx

16. Wenger, E. (2006). Communities of practice: A brief introduction. Retrieved March $\quad 07, \quad 2010 \quad$ from http://www.ewenger.com/theory/

17. Wilson, B. \& Ryder, M. (n. d.). Dynamic Learning Communities: An Alternative to Designed Instructional Systems. Retrieved February 26, 2010 from http://carbon.ucdenver.edu/ mryder/dlc.htm $\underline{1}$ 